\section{Lung Cancer and Smoking}

SIR,-It seems that cigarette smokers adjust the number of cigarettes smok $d$ to obtain a predetermined dose of nicotine (Dr. M. A. H. Russell and others, 1 December, p. 512). Would it not be much safer (no tar), and much cleaner for non-smokers in the vicinity, to market nicotine inhalers, similar to those used by asthmatics? The price of these could be adjusted so that the Government need not lose revenue. The nicotine addicts would presumably not be at risk from bronchogenic carcinoma and chronic bronchitis, and there would be no carbon monoxide to contribute to atheroma formation.-I am, etc.,

Edinburgh

D. R. REDMAN

\section{Diabetic Diarrhoea}

SIR,-The report by Dr. I. R. Condon and others (17 November, p. 423) that cholestyramine relieves diabetic diarrhoea is most interesting.

We have investigated six patients with diabetic diarrhoea using the ${ }^{1 !} \mathrm{C}$-glycocholate breathing test $\mathrm{t}^{1-4}$ and have found it to be normal in all. This makes it unlikely that the diarrhoea is due to increased entry of bile salts into the colon. It is hard to understand why the existence of a large-volume poorly contracting gall bladder should be associated with swamping of the reabsorptive capacity of the disease-free ileum, even if bile is poorly mixed with chyle.

Bile salts have been shown under certain circumstance to affect fluid transfer across the small-bowel mucosa, 5 and there are clearly several ways in which cholestyramine could be acting to relieve diabetic diarrhoea. As well as suggesting a new treatment for the refractory diarrhoea, the report from Eastbourne should stimulate research into how it works.-I am, etc.,

THOMAS S. LOW-BEER

Department of Medicine,

Southmead Hospital,

Bristol

1 Fromm, H., and Hofmann, A. F., Lancet, 1971, 2 Sherr, H. P., et al., New England fournal of Medicine, 1971, 285, 656.

3 James, O. F. W., Agnew, J. E., and Bouchier, I. A. D., British Medical Journal, 1973, 3, 191 . 4 Fromm, H., Thomas, P. J., and Hofmann, A. F., Gastroenterology, 1973, 64, 1077.

5 Wingate, D. L., Phillips, S. F., and Hofmann, A. F., fournal of Clinical Investigation, 1973, 52, 1230.

\section{Bile Acids and Post-vagotomy Diarrhoea}

SIR,-We note with interest the letter from Dr. J. R. Condon and others (17 November, p. 423) discussing the treatment of diabetic diarrhoea with cholestyramine and its possible use in post-vagotomy diarrhoea.

The clinical similarities between postvagotomy diarrhoea and that which follows ileal resection prompted us to measure the total faecal bile acid content of the faeces in patients with severe, continuous postvagotomy diarrhoea, normal controls, and patients who had undergone truncal vagotomy and drainage but did not have diarrhoea. The bile acids were measured by gas liquid chromatography using the method of Everard and Janssen. ${ }^{1}$ We found a statistically significant increase in the total bile acid excretion in the faeces in the post- vagotomy diarrhoea group. There was, however, no significant difference between these pacients and those who had undergone vagotomy and drainage but did not have diarrhoea. 2 The study has been extended since then and further interesting observations have been made.

When individual bile acids were measured there was a highly significant $(P<0.005)$ increase in the excretion of chenodeoxycholic acid in the patients with postvagotomy diarrhoea. Resection and disease of the terminal ileum produce a diarrhoea considered to be due to the cathartic action of bile salts on the colonic mucosa ${ }^{3}+$ and chenodeoxycholic acid is considered to play the major role in this diarrhoea. ${ }^{5}$ Ayulo $^{6}$ has shown considerable improvement in 11 out of 13 patients with post-vagotomy diarrhoea when treated with cholestyramine. We ourselves are at present conducting a doubleblind controlled trial of the drug and hope to be able to report on this in the near future.

Bile acid catharsis is probably involved in a number of patients with post-vagotomy diarrhoea, but the reasons for this are not clear. We would agree in large part with the factors mentioned by Dr. Condon and his colleagues, but would disagree that vagotomy increases bile flow, as Baldwin et al. ${ }^{7}$ have demonstrated reduced bile flow from the liver following vagotomy. We hope that cholestyramine will help patients with this troublesome side effect of surgery and that newer trends in surgery will virtually abolish it. ${ }^{8}$ - We are, etc.,

J. G. Allan V. P. GERSKOWITCH

Department of Gastroenterology,

R. I. RUSSELI

oyal Infirmary,

Glasgow

Everard, E., and Janssen, G., fournal of Lipid Research, 1968, 9, 226.

Allan, J. G., Gerskowitch, V. P., and Russell, R. I., Gut, 1973, 14, 423 .

3 Meihoff, W. E., and Kern, F. jun., fournal of Clinical Investigation, 1968, 47, 261 Hofmann, A. F., and Poley, J. R., Gastroenterology, 1972, 62, 918.

Poley, J. R., Hofmann, A. F., and Ammon, H. V. unpublished data cited

Medicine, 1972, Ayulo, J. A., America

Baldwin, J., et al., American fournal of Surgery, 1966, 111.66 . 6 .

Johnston, D., Humphrey, C. S., Walker, B. E.,
Pulvertaft, C. N., and Goligher, J. C., British Medical fournal, 1972, 3, 788 .

\section{Shortage of Plastics}

SIR,-As we all know, there is a world shortage of plastics. This is now hitting medical supplies, and today in my practice the following items are either rationed or completely out of stock: syringes, dip slides, gloves, tablet containers.

Clearly it is necessary to divert the use of plastics from some non-essentials such as packaging and toys into essential medical supplies. The situation is complicated by the fact that some plastic items of medical use are imported as the finished product. As yet I see no evidence that either the B.M.A. or the Department of Health and Social Security is aware of the full impact of this problem on medical care. It is not insuperable, and they should get together quickly and work out a solution.-I am, etc.,

Peterborough

\section{Medicine in the Open University}

SIR,-Do senior British doctors believe that the Open University, with its present correspondence and regional tutorial methods, could produce a high-standard medical course containing both the preclinical and clinical components of a doctor's training? A random sampling by questionnaire just carried out by the Open University Society for Medical Sciences indicated quite firmly that they do not. But the questionnaire also revealed that a majority felt that an Open University preclinical course was quite possible. Other replies to questions about objections which have been raised to the possibility of entering the profession via the Open University showed that most respondents are not satisfied with the existing selection system, that mature entrants make good medical students, and that the country is still short of good doctors.

The success of the uniaue Open University methods of teaching physical sciences is now generally admitted. The main obstacle to its under aking medical training is the need for patient contact and for the apprentice-master relationship. Is the obstacle insurmountable? These problems and the implications are to be discussed at a conference on "Open Medicine" at Leeds University from 28 to 30 December, with sessions addressed by distinguished guest speakers from the education and medical science fields. Members of the medical professions interested in the ropic will be welcome at the conference, of which an announcement has already appeared in the B.M.F. (1 December, p. x).-I am, etc.,

W. IVOR SHIPLEY Open University Society for Medical Scienan Bromley, Kent

\section{Points from Letters}

\section{Breast-feeding}

Dr. H. B. Valman (Northwick Park Hospital, Harrow, Middx) writes: I agree with Dr. R. L. Rolls (24 November, p. 493) that by improving the public image of the nursing mother breast-feeding will become more popular. ... At this hospital we are just completing a film on breast-feeding which covers all the points raised by Dr. Rolls and will be suitable for mothers in anteratal clinics as well as nursing and medical staff. Copies of the film will be available on loan.

Mr. D. J. Neal Smith (Twickenham) writes: It was refreshing to read Dr. R. D. G. Creery's letter (3 November, p. 299). Most obstetricians, paediatricians, and midwives will agree with him. Yet the present situation of breast-feeding is very largely the fault of these same professional people. Often little advice or encouragement is given to pregnant women, who have usually made up their minds (or had them made up for them) long before their babies are born. In many maternity units patients are actually asked if they want to breast-feed their babies or not-with the emphasis on the "not" rather than the other way round. The very fact of being asked will be taken by many women to mean that it doesn't matter which they choose to do. Of course it takes time to talk to patients about natural feeding, time to discuss the pros and cons with them, time to instruct them before and after delivery, and time, patience, and more encouragement to carry it into practice. Lack of time and the ever-present cry of shortage of staff are excuses rather than reasons, and it is regrettably true that many midwives are badly trained in the subject. ... 